\title{
Detection of Helicobactor pylori by polymerase chain reaction: A comparison in sample preparation
}

\author{
R. Murugesan, P. Bhattacharjee*, P. R. Vivek Kumar**, Mary N. Mohankumar**, Mangala Nagarajan*, \\ R. K. Jeevanram** \\ Department of Biotechnology, Kasturba Medical College, Manipal, *DAE Hospital, DAE Township, **Radiological Safety Division, Indira \\ Gandhi Centre for Atomic Research, Kalpakkam, India
}

Gastric biopsy samples obtained from 14 patients with upper abdominal pain, clinically diagnosed as acid peptic disease, were analysed for the presence of Helicobacter pylori (H. pylori) by Polymerase Chain Reaction (PCR) using partially (template $A$ ) and completely purified DNA (template B). Antigen specific primer was used to analyse the sample by PCR method. The presence of $H$. pylori in the samples was confirmed by running a positive control. The presence of $H$. pylori was also detected by urease method using standard protocol. Among the 14 samples studied, 8 showed the presence of $H$. pylori with both templates A and $\mathrm{B}$. Among these 8 samples only 3 showed positive for the presence of $H$. pylori with urease method. The present work discusses the results obtained in the detection of $H$. pylori in template A and B by PCR method.

Key Words: H. pylori, Gastritis, Duodenal ulcer, Polymerase Chain Reaction, Antigen specific primer

\section{Introduction}

Helicobacter pylori (H. pylori), a micro aerobic spiral gram-negative bacterium, known to be associated with active chronic gastritis and peptic ulcer. ${ }^{[1]}$ Approximately two third of the world population are infected with $H$. pylori. ${ }^{[2]}$ Early detection of $H$. pylori infection may help to prevent gastric related disease..$^{[3,4]}$ It has been reported that $H$. pylori can also cause carcinoma of the stomach. ${ }^{[5,6]}$ A number of diagnostic tests have been developed for the detection of $H$. pylori. This includes cultur- ing of gastric biopsy specimen, ${ }^{[7]}$ rapid urease test ${ }^{[8]}$ and staining and histology technique ${ }^{[9]}$ Culturing of $H$. pylori requires 5 to 7 days of incubation and has been shown to give rise to a false negative value in a number of samples. ${ }^{[10]}$ Urease test although a rapid method but less sensitive in the detection of $H$. pylori and the results show both false positive and false negative values. ${ }^{[11]}$ Histological examination of stained biopsy smears is also a non-specific test and has a low sensitivity for detection of this organism. ${ }^{[12]}$

Several molecular techniques have been developed for the detection of $H$. pylori in gastric biopsy specimen such as dot blot hybridization, DNA-RNA hybridization assay and RFLP methods. ${ }^{[13]}$ All these methods require lengthy processing time ${ }^{[13]}$ and hence not suitable to adopt as a routine procedure in clinical laboratories. In recent years it has been shown that the presence of bacteria in biopsy material can be detected using Polymerase Chain Reaction (PCR). ${ }^{[14]}$ Using this method $H$. pylori has been detected with various primers and the results have been compared with the conventional methods. Most of the studies have shown that the sensitivity of detection of $H$. pylori by PCR method was better compared to other methods. ${ }^{[10]}$ This method though sensitive to detect $H$. pylori has not been used for diagnosis in most of the hospitals. The initial preparation of sample such as purification of DNA and the cost of the reagents 
might be the inhibiting factors to use this technique in the hospitals. It was, therefore, of interest to detect the presence of $H$. pylori in samples obtained after partial and complete purification of DNA using antigen specific primer. The present work discusses the results obtained in samples with partial and complete purification of DNA.

\section{Materials and Methods}

Gastric biopsy samples were collected from ten male and four female patients at DAE Hospital, Kalpakkam, Tamilnadu. Among these 14 patients five were suffering from duodenal ulcer, three from non-ulcer dyspepsia, two from gastritis, two from antral gastritis and two from duodenities. Age of the patients varied between 17 and 50 with an average of 34.5 .

Antigen specific forward 5' (TGG CGT GTC TAT TGA CGA CGA GC) 3' and reverse 5' (CCT GCT GCG CAT TCA CCA TG) 3' primers were procured from Genei (Bangalore GENEI, India).

Detection of $H$. pylori by urease test was followed by the method described elsewhere. ${ }^{[8]}$ The biopsy material was placed in a solution containing $10 \%$ urea, $0.005 \%$ potassium dihydrogen phosphate and phenol red indicator ( $\mathrm{pH}$ 6.8). The change of colour was observed between $30 \mathrm{~min}$ and $24 \mathrm{hr}$. If the colour changes from yellow to pink it indicates the presence of $H$. pylori.

Excised biopsy sample was transferred immediately into a micro-centrifuge tube containing $0.9 \%$ of $\mathrm{NaCl}$ $(500 \mathrm{ml})$ and centrifuged at $12,000 \mathrm{~g}$ for $10 \mathrm{~min}$. The pellet was resuspended in $300 \mu$ of extraction buffer (20 mM Tris- $\mathrm{HCl}, \mathrm{pH} 8.0$; Tween-20, $5 \mu \mathrm{l} / \mathrm{ml}$ ) and $3 \mu \mathrm{l}$ of proteinase $\mathrm{K}(200 \mu \mathrm{g} / \mathrm{ml})$ and kept at $55^{\circ} \mathrm{C}$ for $1-2 \mathrm{hr}$ to ensure complete lysis of the tissue. This was further heated at $98^{\circ} \mathrm{C}$ for $10 \mathrm{~min}$ to inactivate the proteinase K. $2 \mathrm{ml}$ aliquot of the above sample (template A) was removed at this stage for PCR amplification. ${ }^{[10]}$ The remaining solution was extracted twice with a mixture of phenol: chloroform: isoamyl alcohol (25:24:1) and twice with chloroform: isoamyl alcohol (24:1) to get pure DNA. The purified DNA present in the aqueous layer following the above extraction was precipitated with absolute ethanol in the presence of one-tenth volume of $3 \mathrm{M}$ sodium acetate at a $\mathrm{pH} 5.5$ and left at $-20^{\circ} \mathrm{C}$ for $1 \mathrm{hr}$. The precipitated DNA was separated by centrifuging at $12000 \mathrm{~g}$ for $30 \mathrm{~min}$ at $4^{\circ} \mathrm{C}$. The DNA pellet obtained was washed in $70 \%$ ethanol, dried at room temperature and suspended in $40 \mathrm{ml}$ of TE buffer (10 mM Tris, $1 \mathrm{mM}$ EDTA). The purity of DNA was tested by measuring the absorption at 260 and $280 \mathrm{~nm}$ in a spectrophotometer (Hitachi, Japan). The purified DNA (template B) was than amplified using PCR.

The amplification of DNA was carried out in $0.2 \mathrm{ml}$ reaction tubes by PCR using a thermal cycler (PERKIN ELMER 2400). A $50 \mu \mathrm{l}$ reaction mixture consisted $1 \mathrm{x}$ PCR buffer [10 mM Tris $\mathrm{HCl}(\mathrm{pH} 8.3), 50 \mathrm{mM} \mathrm{KCl}, 1.5$ $\mathrm{mM} \mathrm{MgCl}$ and $0.01 \%$ gelatin], four deoxynucleotide at concentrations of $200 \mu \mathrm{M}$ each, forward and reverse primer each at a concentration of $0.1 \mu \mathrm{M}$ and $2 \mu \mathrm{l}$ of template $(A)$ or $1 \mu$ of template $B$. Prior to thermal cycle the genomic DNA was denatured at $94^{\circ} \mathrm{C}$ for $5 \mathrm{~min}$. Following this the sample was allowed to undergo 40 cycle which consisted denaturation of DNA for $1 \mathrm{~min}$ at $94^{\circ} \mathrm{C}$, annealing of primer for $1 \mathrm{~min}$ at $68^{\circ} \mathrm{C}$ and extension of primer for $1 \mathrm{~min}$ at $72^{\circ} \mathrm{C}$. A final extension of DNA was carried out for $5 \mathrm{~min}$ at $72^{\circ} \mathrm{C}$ to ensure complete amplification. Distilled water served as a negative control and cultured H. pylori DNA served as positive control during the amplification. The amplified DNA product was analysed by electrophoresis using agarose prepared in TAE (Tris acetate-EDTA) buffer $(2 \mathrm{~g} /$ $100 \mathrm{ml}$ ). The size of the gel was $10 \times 7 \mathrm{~cm}$ with a thickness of $0.3 \mathrm{~cm}$. Samples were loaded on the gel and a current of $40 \mathrm{~mA}$ was applied. 100-500bp DNA ladder was used as marker to know the size of the PCR product. The sample was allowed to run for $2 \mathrm{hr}$ and the gel was stained with $0.5 \mathrm{mg} / \mathrm{ml}$ ethidium bromide for $30 \mathrm{~min}$. The band was seen by illumination with UV light in a gel documentation system (Advanced American Biotechnology, AAB, USA).

\section{Results}

Table 1 shows the results obtained in samples (template $A$ and $B$ ) with PCR method. The table also shows the results obtained in biopsy samples by urease method. Among the 14 samples studied 3 showed positive with both PCR and urease method. In addition to these three, $H$. pylori was found to be positive in five 
Table 1: Clinical diagnosis and the results of the test carried out in patients with various gastric disorders for the detection of $\boldsymbol{H}$. pylori

\begin{tabular}{|c|c|c|c|c|c|}
\hline $\begin{array}{l}\text { Case } \\
\text { No }\end{array}$ & $\begin{array}{l}\text { Age/ } \\
\text { Sex }\end{array}$ & Diagnosis & $\begin{array}{c}\text { Urease } \\
\text { test }\end{array}$ & $\begin{array}{c}\text { PCR am } \\
\text { Template } \\
\text { (A) }\end{array}$ & $\begin{array}{c}\text { plification } \\
\text { Template } \\
\text { (B) }\end{array}$ \\
\hline 1 & $40 / M$ & Antral Gastritis & - & - & - \\
\hline 2 & $48 / M$ & Gastritis & - & - & - \\
\hline 3 & $30 / F$ & Duodenitis & + & + & + \\
\hline 4 & $37 / M$ & Duodenal ulcer & - & - & - \\
\hline 5 & $17 / M$ & Non ulcer dyspepsia & - & + & + \\
\hline 6 & $39 / M$ & Duodenities & - & + & + \\
\hline 7 & $21 / M$ & Duodenal ulcer & - & - & - \\
\hline 8 & $24 / F$ & Duodenal ulcer & + & + & + \\
\hline 9 & $45 / F$ & Non ulcer dyspepsia & - & + & + \\
\hline 10 & $42 / M$ & Non ulcer dyspepsia & + & + & + \\
\hline 11 & $50 / M$ & Duodenal ulcer & - & - & - \\
\hline 12 & $27 / M$ & Duodenal ulcer & - & + & + \\
\hline 13 & $23 / M$ & Gastritis & - & - & - \\
\hline 14 & $40 / F$ & Antral gastritis & - & + & + \\
\hline
\end{tabular}

Template (A): Partially purified DNA, Template (B): Completely purified DNA, '+: H. pylori positive, ' - : H. pylori negative, M: Male, F: Female

cases by PCR method. The samples, which showed positive with PCR, were observed positive in both templates ( $A$ and $B)$.

Figire 1 shows the amplified DNA products by gel electrophoresis. Among the 17 lanes seen in Figure 1, lane 1 show the bands obtained with molecular weight marker, lane 2 to 15 correspond to the biopsy samples, lane 16 and 17 indicate negative and positive control respectively. Of these samples lane $4,6,7,9,10,11$, 13 and 15 showed the amplification of DNA.

Table 2 shows that $21.42 \%$ of the patients were positive by urease and $57.14 \%$ of the patients were positive by PCR method (both template $A$ and $B$ ). With regards

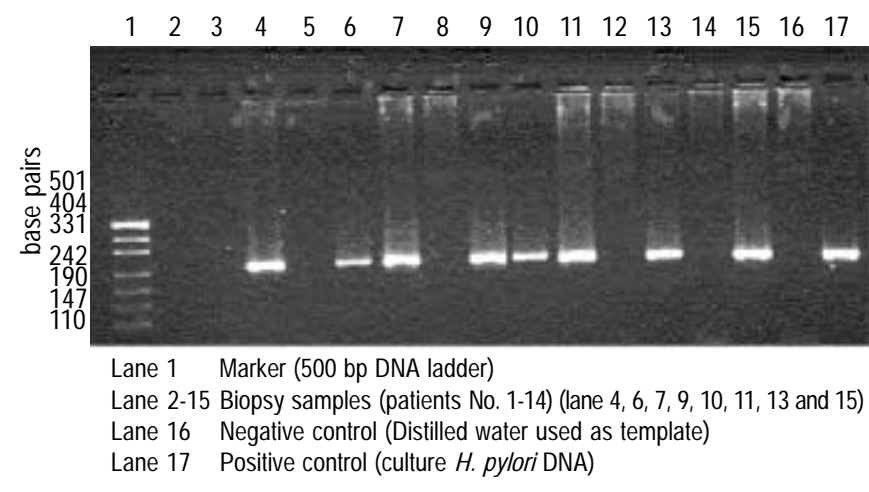

Figure 1: Agarose gel electrophoresis carried out in samples obtained with partially purified DNA after amplification using antigen specific primers
Table 2: Percentage of the samples positive with urease and PCR assay for $\boldsymbol{H}$. pylori

\begin{tabular}{lcc}
$\begin{array}{l}\text { Number of } \\
\text { Patients }\end{array}$ & $\begin{array}{c}\text { Percentage of cases } \\
\text { positive with urease } \\
\text { and PCR test }\end{array}$ & $\begin{array}{c}\text { Percentage of cases } \\
\text { positive with } \\
\text { PCR alone }\end{array}$ \\
\hline 14 & $21.42(3)$ & $57.14(8)$ \\
\hline The numbers in the parenthesis indicate the number of patients. \\
to the concentration of $\mathrm{MgCl}_{2} 1.5 \mathrm{mM}$ was used for PCR \\
study as we observed among the various concentra- \\
tions of $\mathrm{MgCl}_{2}(1.5,2.5$ and $3.5 \mathrm{mM})$ tested during this \\
work only 1.5 mM concentration of $\mathrm{MgCl}_{2}$ gave optimum \\
amplification of DNA.
\end{tabular}

\section{Discussion}

The present study has indicated that among the 14 patients, 8 showed the presence of $H$. pylori in both templates ( $A$ and $B$ ) by PCR method. As per the diagnosis among the 14 patients 11 had ulcer either duodenal or gastric and three had non-ulcer dyspepsia. The 8 patients who showed positive for the presence of $H$. pylori were from the 11 patients who were diagnosed for ulcer. Three patients with non-ulcer dyspepsia indicated absence of $H$. pylori. The 8 patients who showed the presence of $H$. pylori in both the templates indicate that the highly purified DNA was not required for the detection of $\mathrm{H}$. pylori. Similar study carried out by Hammer et al ${ }^{[10]}$ have shown that almost the 27 cases studied 19 showed positive by lysate (partial digestion) and only 11 showed positive with purified DNA. The authors have pointed out that among the 19 positive cases 8 would have become negative during the organic purification of DNA. This could be due to the addition of inhibitory materials or loss of DNA during the organic extraction.

Our study, however, showed positive with both templates indicating that a simple extraction of tissue material (template A) was sufficient to carry out the test. Among the 11 patients who showed ulcer condition by diagnosis only 8 showed positive by PCR method. The absence of $H$. pylori in the remaining 3 cases could be that the region from where the sample collected probably not infected with this organism, as it is known that this organism is present in patches in these patients. At the same time, it should be noted that the samples 
analysed by PCR and urease test were collected from the same regions and thus the absence of $H$. pylori in five out of eight cases as analysed by urease test could be due to the poor sensitivity of detection and not due to the region of sample collection.

At present a number of primers were used to detect the $H$. pylori by PCR method such as species-specific antigen primer, urease gene, 16s rRNA gene. ${ }^{[15]}$ The primer derived from the DNA sequence of a speciesspecific protein antigen has been shown to be present only in $\mathrm{H}$. pylori. Antigen specific primer was selected in this study. O'Toole et al[16] have reported that the DNA sequence of this primer was specific to the antigen present only in $H$. pylori and not found in other bacteria.

Although PCR technique has been shown to be more sensitive in detecting $H$. pylori compared to urease test, $\mathrm{PCR}$ is not being used as a routine diagnostic procedure in many of the hospitals. This perhaps could be due to the cost of the instrument for initiating the work and also the cost of reagents used for the estimation. By considering the sensitivity of the technique in the detection of H. pylori and also its applications in various other diagnostic tests such as Leptospirosis, HIV, Hepatitis B etc the hospitals can justify the use of this technique.

In conclusion the present study has indicated that a simple extraction of tissue sample was sufficient to detect $H$. pylori which will reduce the time and cost of analysis.

\section{Acknowledgments}

Authors are thankful to Dr. Baldev Raj, Director, IGCAR, Mr. S. B. Bhoje, Former Director, IGCAR, Mr. M. Rajan, Director, Safety Group, late Mr. S. Govindarajan Former Director, Safety Group, Dr. R. Indira, Head, RSD, Dr. A. Natarajan, Former Head, RSD and Dr. A. R. Lakshmanan, Head, RASES for their support. Thanks to Mr. T. Rajendran laboratory in-charge for analyzing the samples with urease method and to Dr. Annal and Dr. Meena Nair for their co-operation.
References

1. Marshall BJ, Warren JR. Unidentified curved bacilli in the stomach of patients with gastritis and peptic ulceration. Lancet 1984;1:1311-5.

2. Lee A, The microbiology and epidemiology of Helicobacter pylori infection. Scad J Gastroenterol 1994;201:2-6.

3. Moss S, Calam J, Helicobacter pylori and peptic ulcers the present position, Gut 1992;33:289-92.

4. Labigne A, de Reuse $\mathrm{H}$, Determinants of Helicobacter pylori pathogenesis, Infec Agent Dis 1996;5:191-202.

5. Parsonnet J, Helicobacter pylori and gastric cancer, Gastroenterol Clin North Am 1993;22:89-104.

6. Marshall BJ, Helicobacter pylori, Am J Gastroenterol 1994;89:s116-s128.

7. Goodwin CS, Blincow ED, Warren JR, Waters TE, Sandrson CR, Easton, Evalution of culture techniques for isolating campylobacter pyloridis from endoscopic biopsies of gastric mucosa, J Clin Pathol 1985;38:1127-31.

8. Coudron PE, Kirby DF. Comparison of rapid urease test, staining techniques and growth on different solid media for detection of Campylobacter pylori, J Clin Microbiol 1989;27:1527-30.

9. Schnell GA, Schubert TT. Usefulness of culture, histology and urease testing in the detection of Campylobacter pylori, Am J Gastroenterol 1989;84:133-7.

10. Hammar M, Tyszkiewicz T, Wadstrom T, O'Toole PW, Rapid detection of Helicobacter pylori in gastric biopsy material by polymerase chain reaction, J Clin Microbiol 1992;30:54-8.

11. Borromeo M, Lambert JR, Pinkard KJ. Evolution of "CLOtest" to detect Campylobacter pylori, in gastric mucosa, J Clin Pathol 1987;40:462-3.

12. Simor AE, Cooter NB, Low DE. Comparision of four stains and a urease test for rapid detection of Helicobacter pylori in gastric biopsies, Eur J Clin Microbiol Infect Dis 1990;9:350-2.

13. Morotomi M, Hoshina S, Green P, Neu HC, Logerfo P, Watanabe I, et al. Oligonucleotide probe for detection and identification of Campylobacter pylori, J Clin Microbiol 1989;27:2652-5.

14. Clayton $\mathrm{CL}$, Kleanthous $\mathrm{H}$, Coates PJ, Morgan DD, Tabaqchali S, Sensitive detection of Helicobacter pylori by using polymerase chain reaction, J Clin Microbiol 1992;30:192-200.

15. Ho SA, Holyle JA, Lewis FA. Direct polymerase chain reaction test for detection of Helicobacter pylori in humans and animals, J Clin Microbiol 1991;29:2543-9.

16. O'Toole PW, Logan SM, Kostrzynska T, Wadstrom, Trust TJ. Isolation, biochemical and molecular analysis of a species-specific protein antigen from the gastric pathogen Helicobacter pylori, J Bacteriol 1991;173:505-13. 